This is the author's version of the published paper which is freely available for download. The published format is subject to Elsevier's copyright, but this version is exactly the same.

\title{
Building partnership capacity for the collaborative management of marine protected areas in the UK: a preliminary analysis
}

\author{
Peter JS Jones ${ }^{1}$ and Jacquelin Burgess \\ Environment \& Society Research Unit, Department of Geography, University College \\ London
}

Citation

Jones PJS and Burgess J (2005) Building partnership capacity for the collaborative management of marine protected areas in the UK: a preliminary analysis. Journal of Environmental Management 77(3), 227-243

\begin{abstract}
This paper reports the findings of a preliminary analysis of fifteen case studies of inshore marine protected areas in the UK. It draws on the common-pool resource (CPR) literature and is premised on the thesis that building partnership capacity amongst relevant authorities and resource users provides a critical basis for overcoming collective action problems (CAPs), through the development of incentive structures and social capital, in order to achieve strategic objectives. Particular attention is paid to the influence of statutory marine biodiversity conservation obligations to the European Commission for marine special areas of conservation (MSACs), as these are an important external contextual factor. The risks of imposition and parochialism are outlined and the challenges of taking a balanced approach are discussed. The challenges posed by the attributes of the marine environment are considered, as are those posed by the policy framework for MSACs. The findings are discussed in relation to three questions: (i) which partnership models appear to have the potential to overcome the CAPs posed by inshore MSACs? (ii) what CAPs had to be addressed during the early phase of development of the MSAC co-management regimes? (iii) what are the likely future CAPs for the collaborative management of MSACs that each partnership will need to address? These preliminary findings will form the basis for future studies to analyse the outcomes of these fifteen initiatives, in order to assess the strengths, in various contexts, of different approaches for building resilient and balanced, thereby effective, institutions for the co-management of MSACs in the UK.
\end{abstract}

\footnotetext{
${ }^{1}$ P.J.Jones@ ucl.ac.uk, tel +44 (0)20 7679 5284, fax +44 (0)20 7679 7565, Dept of Geography, Remax House, University College London (UCL), London WC1E 7DP, UK
} 


\section{Introduction}

This paper explores issues related to the governance of common-pool resources (CPRs), particularly the collaborative management (hereafter referred to as co-management) of inshore marine protected areas (MPAs) in the UK. It is premised on the thesis that multi-sector partnerships have the potential to overcome collective action problems (CAPs) through the development of incentive structures and social capital in order to achieve strategic objectives. The analysis pays particular attention to the importance of external contextual factors in these CPR governance initiatives, as the statutory marine biodiversity conservation obligations to the European Commission (EC) are a critical factor in the case studies. Much CPR research is focused on the development of capacity amongst local resource users to sustainably manage their natural resources. Other research is focused on the development of state capacity amongst relevant authorities (RAs) to enforce natural resource management decisions. This paper focuses on the relationships amongst both resource users and RAs through an emphasis on new institutional relations that may build partnership capacity to achieve statutory marine biodiversity conservation objectives. These objectives are focused on maintaining the quality and quantity of a range of natural features and are thus wider than the objective of sustainable resource exploitation, on which many CPR case studies have been based. The distribution of power and the capacity of the partnership to be institutionally sustainable whilst also fulfilling wider statutory marine biodiversity conservation objectives are therefore important issues in the analysis.

One significant problem in the evaluation of more inclusive forms of decision-making, especially in terms of assessing substantive outcomes, is the lack of ex ante evidence about the issues that emerged during the preliminary stages of the development of management regimes, which may well prove critical in terms of subsequent events. This study, therefore, provides an unusual and potentially valuable insight into the beginnings of co-management schemes for the implementation of inshore marine special area of conservation (MSAC) initiatives in the UK. Evidence is taken from research which explored the early stages of the development of different approaches for promoting the participation of resource users and RAs (government departments, agencies, etc with responsibility for the management of marine issues such as fisheries, navigation, recreation, pollution, mineral extraction and coastal development) in fifteen MSAC case studies. These sites were the subject of an initial selection consultation in March 1995 and at the time of the work (1999-2001) management schemes were still being negotiated.

The paper begins with an overview of the principles of CPR governance and the links between this and the co-management of protected areas, particularly MPAs. It then discusses the need to balance top-down and bottom-up priorities, and introduces the concept of partnership capacity. The marine context within which these issues are explored is then outlined, including an outline of the challenges posed by the attributes of the marine environment and of the specific policy context for inshore MSACs in the UK. The findings of the fifteen case studies are then discussed in relation to three questions: (i) which partnership models appear to have the potential to overcome CAPs in the development of the UK's inshore MSACs? (ii) what CAPs had to be addressed during the early phase of development of the MSAC co-management regimes? (iii) what are the likely future CAPs for the co-management of MSACs that each partnership will need to address if it is to be successful? Future research will return to these case studies to evaluate ongoing progress, particularly the outcomes in terms of both the resilience of the MSAC management regimes and their effectiveness in achieving statutory marine biodiversity conservation objectives. 


\section{Governance of CPRs and the case for co-management}

There has been much debate on how best to manage CPRs (Dietz et al. 2002), Ostrom (1990, 1998, 1999) arguing that new institutional arrangements, notably local partnerships between different actors, can be effective in achieving strategic management objectives for CPRs. On the basis of detailed analyses of many different case studies where there were real or potential conflicts between individual users of a CPR, Ostrom identified the potential benefit of new governance mechanisms that support the development of mutual trust and cooperation amongst actors, with the state's role shifting from control to facilitation. More recent work complements Ostrom's analysis by highlighting the critical importance of local (McCay 2002) and external (Edwards and Steins 1999) contextual factors in CPR governance initiatives.

The governance of CPRs generally requires several challenges to be addressed. These are referred to as collective action problems (CAPS), and are the hurdles that need to be overcome if commitment, cooperation and compliance is to be developed amongst CPR users and regulators, who are generally described as actors. The tendency of some actors to lack commitment, cooperation and compliance and to behave accordingly in an opportunistic manner is generally referred to as free-riding. The social processes that may bind actors through a multi-sector partnership to address such CAPs and minimise free-riding are often described in terms of social capital. This is a measure of the degree to which actors reach and implement decisions together through their professional and social networks, placing trust in one other, and having confidence that their cooperation will be reciprocated. The social capital approach seeks to modify institutional design and policy processes so that incentive structures are developed that encourage and support actors in overcoming CAPs. Incentive structures are particular types of institution, including shared norms and enforcement laws, that encourage or require cooperation amongst resource users (Ostrom, 1990, 1998, 1999). Rydin and Pennington (2000) build on Ostrom's work in the context of local environmental initiatives in England. Such studies provide an interesting analytical perspective to assess whether and how the development of social capital and incentive structures can help produce 'better' and more effective policy outcomes with reference to achieving strategic nature conservation objectives.

There has been growing interest in the development of partnerships to achieve strategic nature conservation objectives through the governance of protected areas. Recognition has grown over the last two decades that local people affected by such initiatives should be involved in their planning and management to increase the fairness of decisions and promote local ownership and cooperation. This key aspect of the new paradigm for protected areas was recognised at the IUCN's 5th World Parks Congress (Phillips 2003). The term 'collaborative management' (hereafter referred to as 'comanagement') describes a range of approaches to provide for the participation of different actors in protected area management. It is recognised as a "broad concept spanning a variety of ways by which the agency in charge and other stakeholders develop and implement a management partnership" (Borrini-Feyerabend 1999, 228). Such participatory approaches are increasingly recognised as being of importance in the UK (Warburton 1998) and there is generally much optimism about the benefits and potential of co-management.

There is also considerable interest in the potential of co-management for MPAs, e.g. Kelleher (1999) and Clifton (2003), and for marine fish stocks, e.g. Jentoft (2003), Nielsen and Vedsmend (1999), Nielsen et al. (2004), Pomeroy et al. (2001) and Wilson et al. (2003). Pomeroy et al. (2001) specifically identify the importance of establishing trust and mutual respect amongst partners, of involving fishers in problem recognition and objective setting, of empowering fishers, and of developing incentive structures to induce participation in collective action to manage fisheries. As such, their arguments for co-management draw implicitly on concepts of social capital. Similarly, but 
in the context of MPAs, Kelleher (1999) emphasises the critical importance of deep stakeholder involvement through the development of partnerships based on trust in order to promote cooperation with MPA initiatives. More explicit reference to the role of social capital in MPA management is made by Rudd et al. (2003) who discuss it as a means of reducing enforcement costs and free-riding. These arguments reveal considerable interest in the potential role of social capital development in the promotion of co-management for marine resource management. This interest has, however, been largely focused on the potential for the sustainable exploitation of fisheries, and this paper provides a contribution by focusing on the potential of Ostrom's (1990) 'new institutionalism' approach to achieve statutory marine biodiversity conservation objectives through the development of social capital to support MPA designations. There are divergences between sustainable fisheries exploitation and marine biodiversity conservation objectives that may have significant implications for the development of social capital to achieve such objectives (Jones, in press).

This analysis will also pay particular attention to the role of local and external contexts in the case studies, particularly, with regards to the latter, the role of the EC and the related potential for state interventions. Whilst it will draw on the new institutionalism literature, it is important to bear in mind that most of the case studies on which this literature is based have been purposefully selected to represent contexts where the emphasis is on self-governance by self-organised local actors (Ostrom 1990). This analysis therefore represents an interesting preliminary assessment of the degree to which new institutionalism approaches are appropriate where the role of the state and the related potential for legal interventions are important external contextual factors.

\section{The risks of imposition}

Criticisms of participation and co-management are beginning to emerge, based on their potential to undermine local governance institutions through their top-down imposition. Cooke and Kothari (2001) argue in the context of developing countries that participation may be 'the new tyranny', imposing goals and institutions on local people, overriding existing legitimate decision-making processes, reinforcing the interests of the already powerful and displacing other potentially beneficial approaches. Jentoft (2004) discusses how some initiatives run contrary to rational choice theory, in that actors start out with a solution and then seek problems to apply it to. Using MPAs as an example, he argues that initiatives are often pursued because they are perceived to fit well with some pre-conceived, general ideas of what constitutes good governance, but that their inappropriate implementation may lead to resistance and failure. Nichols (1999) argued that this was indeed the case with collaborative MPAs funded by development organisations in Indonesia which subverted traditional resource management systems and promoted market-economics driven exploitation by external interests.

Proponents of co-management also have concerns that protected areas pursued as part of a national policy initiative risk being too 'top-down' to provide for the meaningful participation of local resource users, given that most protected areas are identified by national decree and RAs decide if and how to involve resource users (Borrini-Feyerabend 1999). They may be too top-down if the RA assumes a controller role, consistent with the "bureaucratic impulse to retain central authority" (Murphree 1994), imposing management structures at too high a level, rather than facilitating their development from the bottom-up (Rydin and Pennington 2000). The critical risk is that the imposition of management institutions will produce local resistance, resulting in the deterioration of the resource system, even though user groups may appear to be accepting of imposed institutions (Edwards and Steins 1999). One outcome in this case would be the designation of what could be described as a paper park: formally recognised but beyond the RA's capacity to manage (Murphree 1994, 407). 
Worse still, there is the prospect that MPAs, even those pursued on a well-meaning collaborative basis, could repeat and extend the interpretation of tragedy of the commons discussed by Dietz et al. (2002). Such initiatives could be interpreted as representing central government appropriation through the imposition of a regime which undermines local governance institutions. Coupled with a lack of state capacity to enforce the MPA regime, this could in effect lead to competitive over-exploitation of the resources of the MPA where these had previously been managed through local governance institutions.

\section{The risks of parochialism}

At the same time, other analysts of co-management raise the troubling question as to whether local initiatives are necessarily better than centralised ones for achieving conservation objectives (Western and Wright 1994, 10). For example, there may be different views between local resource users and RAs concerning the importance given to national objectives in relation to local concerns (Goodwin 1998; Pennington and Rydin 2000) which could undermine the potential for cooperation. Parochial objectives may even conflict with national ones, leading to a fragmentation of conservation visions and a failure to achieve strategic objectives, a risk to which that the nature conservation agencies (NCAs) are sensitive (Goodwin 1998, 1999).

Goodwin (1999) argues that local participation will make the maintenance of a national conservation vision and the legitimacy of NCAs and their ideas more difficult to maintain. He concludes that greater institutional reflexivity is required to reconceptualise meanings of participation and conservation. By focusing "on participation as a process, in which the objectives and actions are not settled in advance but emerge from the act of participation itself", it becomes possible to argue that the goals of nature conservation are subject to interpretation and re-interpretation in different localities. McClanahan (2004) discusses this in the context of the IUCN's 5th World Parks Congress (Phillips 2003), suggesting the co-management paradigm could lead to a continual reclassification of what constitutes conservation. He believes this could lead to a hollow victory: protected area approaches that successfully promote resource user participation could result in a "picked-over and emaciated carcass of biodiversity". Such claims are premised on the risk that resource exploitation and economic development objectives will dominate local decision-making processes, over-riding strategic nature conservation objectives. Walters (2004), for instance, shows how a mangrove conservation project in the Philippines, which is recognised as a success story for community-based conservation, may be undermining conservation objectives by the gradual replacement of natural mangroves with mangrove plantations, through a focus on local resource exploitation interests.

\section{Taking a balanced approach}

The critical issue, therefore, in co-management regimes, is how power is allocated and shared between the different partners, taking power to be the potential to take decisions that are binding on other actors by mandate and/or influence. In many cases, the government agency will be 'in charge' but comanagement critically relies on the development of partnerships with resource users. The internal flaw in this logic is succinctly highlighted by Geisler (2002): "I expropriate you, then invite you to be my management partner. Precarious power logic; perfidious results." The different means of addressing the critical challenge of forging partnerships with local resource users who may have become more bound by the powers of the state, through the designation as 'protected' of the area in which they undertake their activities, is a key focus for the fifteen case studies in this paper. It is increasingly accepted by proponents of co-management for protected areas that such approaches do not always work, i.e. partnerships are not forged, or CAPs are not addressed or cannot be overcome, and that 
failure comes not only at a heavy cost of time and effort, but perhaps more significantly, at a cost of social capital consumed rather built (Conley and Moote 2003).

With regards to the sharing of power and the fulfilment of statutory obligations, particularly to the EC under the Habitats Directive, the argument above that conservation objectives should emerge from local participation clearly has fundamental implications for NCAs and the UK Government. The European Court of Justice is unlikely to accept a government's defence that statutory conservation objectives were not fulfilled because they were not consistent with the objectives that emerged from local participation processes. If such objectives are pursued through top-down approaches, they run the risks of imposition and are unlikely to be achieved in the face of resource user apathy, protest and defiance against a background of a lack of state capacity to rely on legal enforcement. If a bottom-up approach is followed, based on local perceptions and priorities, such objectives run the risks of parochialism and are unlikely to be achieved unless they converge with the objectives that emerge as a result of local deliberations. In this respect, Berkes (2002) notes that "the balance of evidence from the commons literature of the past few decades is that neither purely local-level management nor purely higher level management works well by itself".

One of the 33 critical conditions for sustainable CPR governance institutions reviewed by Agrawal (2001) is that central governments should not undermine local authority, and this is also considered to be one of three basic necessary conditions by Stern et al. (2002). Another condition is that there should be 'nested' levels of appropriation, provision, enforcement and governance. This condition recognises that there will be different levels of decision-making (Figure 1), from the establishment of legal frameworks within which resource users have to operate, through to the establishment of organisational frameworks including rules for interaction between RAs and resource users, and operational frameworks including day-to-day rules controlling access to, allocation of and control over resources (Ostrom 1990). This potentially provides for an approach to address the top-down/bottomup dilemma in keeping with a more progressive definition of co-management: "power-sharing in the exercise of resource management between a government agency and a community or organization of stakeholders" (Pinkerton, 1992).

In this context Berkes (2002) discusses the importance of vertical linkages, whereby there is coupling or interactions between different levels of the governance structure. Such vertical linkages are important for the 'nested' approach discussed above. They provide for local partnerships to operate under interaction rules within an organisational and legal framework (Figure 1), including statutory obligations. It is argued that the interactions between the nested levels, particularly top-down interventions driven by these obligations, must be carefully managed in order to avoid critically undermining local authority. Stern et al. (2002) note that such linkages are extremely challenging for the management of global biodiversity because of the different objectives of governance at different levels. This is in keeping with the discussions above on the risks of parochialism and the divergence between sustainable resource exploitation and biodiversity conservation objectives. The linkage of local, national and EC management institutions to achieve a balance between local and strategic objectives is therefore very challenging to achieve. This challenge is arguably one that has been neglected by the CPR literature in its focus on local institutions and neglect of external contexts (Agrawal 2001, Berkes 2002, Edwards and Steins 1999) and is one that Stern et al. (2002) identify as a priority for future CPR studies.

\section{[Figure 1]}

Clearly, partnerships are central to both the concept of co-management and the achievement of the balance discussed above. The potential of different structures and approaches to achieve such a 
balance might be assessed in terms of partnership capacity. Rudd et al. (2003) review arguments that many renewable resource management case studies do not sufficiently take account of, inter alia, power relations between resource users and the state (Agrawal 2001, McCay and Jentoft 1998), whilst Steins and Edwards (1999) identify power relations in nested platforms as a priority for further research. The power relations in the partnerships between different levels of governance structures are clearly critical to the establishment of vertical linkages and the balanced approach discussed above.

Such a balanced environmental governance approach is outlined by Rydin and Pennington (2000) in the specific context of environmental initiatives in the UK. With regards to MPAs, Jones (2001) argues for a 'middle ground' approach which balances local and national perspectives and concerns, whilst Kelleher (1999) stresses that the design and management of MPAs must be both top-down and bottom-up. Our research takes these arguments forward by exploring to what extent, in the establishment of new institutional arrangements to implement UK MSACs under the Habitats Directive, there were commitments to developing partnership capacity. This can be defined as the capacity amongst RAs and stakeholders to develop incentive structures to overcome CAPs through the sharing of power and the promotion of mutual trust, confidence and cooperation. A critical issue for the analysis of different approaches to developing partnership capacity will be their potential to establish power relations through vertically linked and nested institutions that can provide for a balance to be achieved between local resource use and strategic conservation objectives. This is arguably a critical issue for the co-management of protected areas in general. If this balance cannot be achieved, the potential of co-management to achieve strategic conservation objectives may be critically undermined.

\section{The emergence of co-management regimes for the UK's inshore MSACs}

Fifteen MSACs throughout the UK (see Figure 2 and Table 1) were studied in research commissioned by the four NCAs for the $\mathrm{UK}^{1}$ as part of the EC co-funded UK Marine SACs Project. The aims of the research were to identify how the MSAC officers were developing the management structures and institutional arrangements and to provide initial guidance on the degree to which different approaches to actor engagement were felt to be appropriate for the early stages of designation for each site.

[Figure 2 and Table 1]

Each MSAC had a dedicated project officer and/or an NCA employee whose responsibilities were primarily focused on the MSAC (both PO hereafter). Site visits and long, semi-structured interviews, lasting between 2 and 5 hours, were carried out in the summer of 1999 with the PO(s) for each of the fifteen MSAC case studies. Each interview covered the history of RA and resource user participation in the MSAC, and the PO's experiences and perspectives on key process issues such as the role of science in the designation process, the professional networks they were working within to progress the management structure and the impacts of different regulatory requirements on progress towards achieving the conservation objectives. All the interviews were audio-taped. A document outlining the key issues and themes from the interview was sent to each PO for their comments and corrections. An executive summary of the draft final report was sent to a sample of RAs and resource users who had participated in the MSACs, and this was followed up by telephone interviews in February-March $2001^{2}$. The RA and resource user representatives were asked to comment, from their different perspectives, on the strengths and weaknesses of the management structures and institutional arrangements that were emerging on their site. A full copy of the research report is available (Jones et al. 2001) 
In the subsequent analyses for this paper, we shall first outline the specific CAPs that marine, relative to terrestrial sites, present to co-management initiatives We will then outline the legal and policy frameworks within which the MSAC sites were operating. This will provide the background to the subsequent discussions of the preliminary findings of the case studies.

\section{CAPs posed by marine attributes}

There are a number of important differences between terrestrial ecosystems, in which the majority of CPR case studies have been based, and marine ecosystems, where the latter has certain attributes that pose challenges for CPR governance initiatives, which can be considered as CAPs. These attributes are reviewed in detail by Jones (2001) but their implications in terms of the CAPs they pose can be summarised as follows.

Scale and connectivity: marine habitats and species tend to have relatively wide distributions, with many species actively or passively moving over hundreds or even thousands of km's in their life cycles. Areas that are spatially separated are more likely to be functionally connected in marine ecosystems than in terrestrial ecosystems, and there is a much greater potential for externally derived impacts to affect a given area, undermining the local motivation to act (Berkes 2002). These interrelated attributes pose particular challenges as they mean that marine living resources tend not to be localised and are therefore not consistent with four of the resource system characteristics that some argue to be critical resource system conditions for sustainable CPR governance reviewed by Agrawal (2001), i.e. small size, well-defined boundaries, low levels of mobility and possibilities of storage of resource benefits.

Variability: marine ecosystems tend to be relatively complex and display high degrees of variability, and it can be extremely difficult to predict the impacts of human interventions and to attribute observed variations to particular natural or anthropogenic causes. This means that marine ecosystems tend not to be consistent with the resource system condition (Agrawal 2001) of predictability, a challenge that is compounded by our relatively poor understanding of the complex dynamics of marine ecosystems.

Naturalness: marine habitats are impacted by many human activities, particularly fishing, but these altered habitats are very rarely considered to be of conservation value in themselves, in the way that terrestrial semi-natural habitats are. Whilst the continuation of certain human activities is often essential to the preservation of such terrestrial habitats, particularly in the UK, marine conservation tends to be focused on excluding certain activities in order to conserve habitats in as natural a state as possible. This can be perceived as a human exclusion approach which may alienate stakeholders.

Low levels of awareness: most people have a relatively low level of awareness of the conservation value of marine habitats and species and of the impacts of human activities on these. It may therefore be more of a challenge to spread an understanding of the need for conservation measures and to generate support for such measures.

Multiple use: marine resources are subject to a variety of different property rights: common, open, public and, more rarely, private, and these resources are subject to a variety of uses by different users. As such, they are very good examples of multiple-use CPRs (Edwards and Steins 1999), which raises a number of CAPs. These include reconciling internal and basic conflicts (Jones 2001) between primary, secondary and tertiary users (Selsky and Creahan 1996), and overcoming hurdles to collective action raised by the related heterogeneity of resource interests and lack of shared norms 
(Baland and Platteau 1996, 304). Furthermore, the representation of multiple interests raises challenges in that institutional frameworks will need to accommodate different user groups and their multiple-interests (Steins and Edwards 1999).

\section{Legal and policy frameworks}

The EC Directive on the Conservation of Natural Habitats and of Wild Flora and Fauna (92/43/EEC, hereafter the Habitats Directive) was enthusiastically welcomed by marine conservationists in the UK as the previous policy framework had led to the designation of very few MPAs and these were weakly protected (Jones 1999). The Directive places an unprecedented obligation on EU Member States to designate MSACs as a means of maintaining the favourable conservation status (FCS) of certain listed marine habitats and species, as part of the Natura 2000 network across the EU, and 70 inshore MSACs are being established in the UK alone, representing $5.6 \%$ of the territorial waters area.

The requirements of the Habitats Directive have been transposed into UK legislation through the Conservation (Natural Habitats etc.) Regulations (1994) and the Conservation (Natural Habitats etc.) (Northern Ireland) Regulations (1995), hereafter referred to collectively as the Regulations. On land above the low water mark, habitat conservation is underpinned by legislation to protect Sites of Special Scientific Interest. However, there was no existing legislative framework for implementing the Habitats Directive below the low water mark. The Regulations, therefore, provide specific new responsibilities and measures in relation to MSACs. They require RAs to work together to establish a management scheme (hereafter scheme) for each MSAC and it is expected that one RA will normally take the lead. All the RAs have an equal responsibility to exercise their functions in a manner that ensures compliance with the Habitats Directive by maintaining the FCS of the features for which MSACs have been designated.

The Regulations do not provide any one RA with an overriding power over other RAs in the development and implementation of a scheme. The process, therefore, relies upon cooperation amongst the RAs for each MSAC, albeit cooperation that is a statutory obligation. However, certain powers are reserved to Ministers to direct the RAs to take specific actions in the event that the scheme is failing to conserve MSAC features. The policy guidance for MSACs (DETR 1998) advises that the RAs should form themselves into a management group to oversee the process of establishing a scheme for a site. The guidance strongly recommends that other groups, including riparian owners/occupiers, marine resource users, industry, local people and interest groups, be involved in developing the scheme. These will be collectively referred to as stakeholders in the subsequent discussions. To achieve this, the guidance suggests the formation of advisory groups and regular stakeholder consultations during the development and operation of the scheme.

The Regulations provide two advisory roles for the UK's NCAs but give them no overall executive powers in MSAC management processes. At an operational level, the NCAs are responsible for advising their partner RAs as to the conservation objectives of the site, and of the types of operations which are likely to cause deterioration or disturbance to conservation features (hereafter objectives/operations advice). At a strategic level, the NCA's National Council formally approves each MSAC scheme put forward, and if it considers that the scheme will not achieve the maintenance of FCS, it can request that appropriate measures be taken. Failing this, Council may advise the Environment Minister to exercise his/her powers under the Regulations and require such measures be taken by the RAs. Ultimately, the European Court of Justice may step-in and require the UK government to take steps to maintain the FCS of MSACs. Furthermore, the policy guidance states that the voluntary principle should apply as far as possible when securing the compliance of MSAC users. 
Statutory enforcement of schemes should only be used as a last resort when it becomes clear that voluntary measures are not proving effective. The policy guidance also directs the NCAs to presume that compatible day-to-day uses of the areas will continue

The contrast between the powers afforded to the NCAs to manage MSACs compared with those for terrestrial SACs could not be clearer. Terrestrial policies are underpinned by private property rights which enable the NCAs to enforce statutory management agreements on specific owners/occupiers, restrict the activities of visitors, and, as a last resort, purchase land in order to promote appropriate conservation management (Reid 2002). Marine policies, without the historic basis of private property rights, are essentially based on a partnership approach amongst RAs and stakeholders which relies primarily on voluntary cooperation in order to achieve statutory obligations, with legitimate coercive powers available only on a back-up basis. The management of MSACs thus presents new challenges to the NCAs, whose experiences and expertise have been developed and honed through terrestrial conservation. Against this legal and policy background, MSACs provide an interesting arena to explore CPR governance issues in a marine context in which there are strong external legal obligations and hence the potential for government interventions. This paper focuses particularly on how power is shared amongst RAs and stakeholders in order to develop partnership capacity and achieve the balance discussed above, with the Habitats Directive, European Court of Justice rulings and the regulations forming the legal framework, the EC/UK policy guidance, MSAC management structures and the scheme forming the organisational framework, and the implementation of the management institutions forming the operational framework (Figure 1). The timetable for MSACs is discussed in the section below on CAPs that have had to be overcome.

It is important to note that all the MSAC case studies were inshore, i.e. within $6 \mathrm{~nm}$ of the coast. The UK government selected the MSACs to be within $6 \mathrm{~nm}$ as this is the zone within which fisheries are managed under UK jurisdiction. Fisheries beyond $6 \mathrm{~nm}$ are partially managed under the EC Common Fisheries Policy (CFP), whilst those beyond $12 \mathrm{~nm}$ are entirely managed under the CFP, therefore any fisheries management measures for nature conservation objectives for MSACs beyond 6nm will need to be negotiated and implemented through the CFP. This will add further complexity to the MSAC management regimes, which is why the UK Government ensured that the initial MSACs were within $6 \mathrm{~nm}$. MSACs beyond $6 \mathrm{~nm}$ are currently being proposed, but the discussions in this paper are focused on MSACs that are managed under UK fisheries policies.

\section{Discussion}

In the light of these important contextual issues, we now turn to discussion of the different models that were emerging for the management of the fifteen sites. It is stressed that this is an ex ante analysis based on case studies of the structures and processes that were being employed at the very early stages of the MSACs to develop the schemes. None of the schemes had yet been finalised therefore the issues that will emerge when the schemes are operationalised cannot be discussed at this stage, though they will be the subject of future research.

\section{Which partnership models appear to have the potential to overcome CAPs in the development of the UK's inshore MSACs?}

A key challenge in developing partnership capacity is to ensure that the institutional structures employed are balanced, as discussed above, in that they provide for power to be appropriately shared amongst RAs and stakeholders, and are appropriate for the local contextual factors that characterise each MSAC. A critical issue in this respect is how and by whom were the institutional structures 
designed? Table 2 provides summary information from the study on which the following discussions are based, whilst Figure 3 illustrates the different management structures.

[Table 2 and Figure 3]

Six of the sites adopted the two-tier management structure recommended by the policy guidance (DETR 1998), whereby the RAs retain executive decision-making powers through the management group (MG). Stakeholder input is restricted to information/advice and consultation response provision through an 'Advisory Group' (AG). In some cases 'Topic Groups' (TGs) were also formed to discuss specific issues such as tourism development, fisheries management, awareness raising and research/information provision. In two of these cases (Solway Firth, Morecambe Bay) previous estuarine management partnership (EMP) structures were adopted. In one case (Chesil \& the Fleet), a previous management structure developed by the private estate was adopted, with the addition of a new group for farmers, whilst in another case (Strangford Lough) a previous MNR structure was adopted which provided the stakeholders with a major role. In the Welsh sites (Cardigan Bay, Llyn Peninsular \& the Sarnau), the two-tier structure was adopted by the RAs in accordance with the policy guidance, but this appeared to undermine the willingness of stakeholders to become involved in the AG due to the intangibility of their potential role.

Five sites employed federated two-tier management structures whereby hierarchies of structures were established to cover different territories. These very large sites straddled national boundaries and/or comprised distinctive geographical regions. In three of these cases (Berwickshire \& North Northumberland Coast, The Wash \& North Norfolk Coast, Solent/South Wight Maritime) there was an overarching MG with separate AGs for different geographical areas, whilst in two cases (Plymouth Sound and Estuaries, Essex Estuaries) there were separate two-tier EMP structures for different areas.

Four of the case studies developed flat management structures whereby the RAs and stakeholders share power on a single-tier group. Three of these cases (Papa Stour, Loch Maddy, Sound of Arisaig) were found in the Highlands and Islands of Scotland, where there are relatively small populations of stakeholders whose dependence on marine resources is relatively high, both important influences for more substantial stakeholder participation in such initiatives (Edwards et al. 1997). It is also noteworthy that the democratically elected councillors played a much more significant role in the development of the institutional arrangements in these three locations. There was also a considerable emphasis on face-to-face meetings between the PO and local stakeholders which is clearly feasible in these small populations and is recognised as a very positive influence on the promotion of social capital (Ostrom 1998, 1999). In the Thanet Coast MSAC, the PO tackled the problem of building consensus for the MSAC among a very large, disparate, geographically dispersed and largely unsympathetic set of RAs and stakeholders by commissioning a programme of professionally facilitated 'stakeholder dialogue' workshops prior to the implementation of the management group. This approach is consistent with arguments concerning the importance of independent facilitation in discussions amongst multiple-interests on CPR 'platforms' (Steins and Edwards 1999). An important feature of all four cases is that they placed a significant emphasis on the compatible economic development opportunities that would be promoted by the MSAC designation, such as tourism development and eco-labelling schemes for local marine produce.

When considering the relative merits of these different management structures it is important to consider Ostrom's $(1990,90)$ design principle concerning the right of stakeholders to devise their own institutions without being challenged by external authorities. Similarly, Rydin and Pennington (2000) argue that stakeholders must be encouraged to build and develop institutions rather than have them imposed from above. Even in the four case studies with flat management structures, the RAs devised 
the institutional arrangements rather than the stakeholders, though some of the specialist topic groups were devised by stakeholders.

With regards to the degree of power-sharing amongst the RAs and stakeholders, Ostrom (1990) and Agrawal (2001) argue that two main principles have emerged as critical to the success of the governance of CAPs: the devolvement of power and the right of access to decision making. Ostrom (1990) also argues for the related principle that the state's role should shift from that of 'controller' to 'facilitator', allowing considerable local autonomy whilst providing a supportive framework. In the four cases where flat management structures were adopted, these principles initially appear to have been fulfilled. In the majority of cases with two-tier and federated two-tier structures they arguably have not. At the time of the research (1999-2000), this only appeared to have been an issue in the two case studies in Wales where the willingness of stakeholders to participate in the AGs was arguably undermined as a consequence of the lack of influence accorded their contributions (see Goodwin 1998).

However, Rydin and Pennington (2000) argue that in cases where CAPs are severe, it is often appropriate to adopt a more top-down government approach, as this is the only feasible way of addressing major conflicts. In many of the eleven case studies with two-tier structures, this was the case. The most extreme example is that of the Solent/South Wight Maritime which, at the time of the research, was divided by bitter conflicts over the development of a new container terminal at Dibden Bay, and between recreational sailors and conservationists. Federated two-tier structures had been adopted in five sites, partly to address their geographically disconnected nature, but also to provide for a degree of devolvement through the establishment of more localised management structures, though these were still essentially two-tier. The federated two-tier structures are consistent with Berkes' (2002) arguments that CPRs need to be managed at a variety of different scales, in which horizontal (across geographical space) as well as vertical (between different institutional levels) linkages are important. In this respect it is important to remember that each MSAC is itself part of the Natura 2000 network of SACs and SPAs (Special Protection Areas under the Birds Directive, 1979) across the European Union and that the EC's main focus is to develop horizontal and vertical linkages within this network.

In several sites with two-tier management structures, the potential for undermining stakeholder participation was minimised by ensuring that the AGs/TGs were allocated specific, tangible tasks, the influence of which on scheme preparation processes was significant and explicit. This is consistent with Young's (2002) argument that a key to the success of integrating decision making across different institutional levels is "allocating specific tasks at the appropriate level of social organisation and then taking steps to ensure that cross-scale interactions produce complementary rather than conflicting actions". By such approaches the interactions between the three organisational levels (Figure 1), particularly interventions from the legal level, can potentially be carefully managed to achieve the balance discussed above. A key question for future research will be whether, in all fifteen case studies, but particularly the eleven with two-tier structures in keeping with the policy guidance, such approaches generate sufficient partnership capacity to overcome future CAPs.

\section{What CAPs had to be addressed during the early phase of development of the MSAC co- management regimes?}

An important issue that emerged in several of the case studies was the manner in which the provision of the objectives/operations advice for each MSAC was managed by the relevant NCA. This represented legal advice and the NCAs took the decision to delay this whilst a rigorous and nationally 
consistent basis for this advice was developed. Despite the fact that most of the fifteen initiatives had deadlines to meet for the delivery of the completed schemes, as discussed below, in some cases the NCA attempted to halt scheme preparation processes until the objectives/operations advice had been delivered. This was in order to ensure that these processes did not proceed on a flawed basis, requiring significant revisions to be made when the advice was delivered. However, many RAs and stakeholders perceived this to be an expression of the NCA's powers. The manner in which these interventions was managed varied. In some cases the stakeholders and RAs were given tangible roles in advice preparation and were given the go-ahead to proceed with scheme preparation processes on the accepted understanding that some aspects might have to be revised once the objectives/operations advice was delivered. In other cases the NCA attempted to order the cessation of such processes until the objectives/operations advice had been delivered, and these interventions significantly undermined the potential for partnership capacity development by alienating stakeholders and RA representatives.

Another issue that emerged was the manner in which the MSAC management structures built on existing institutions. Pennington and Rydin (2000) discuss the importance of harnessing the positive attributes of existing institutions as this provides for social capital generated in overcoming one set of CAPs to be built upon in order to solve further dilemmas. This approach utilises one of the key characteristics of social capital, i.e. it actually increases in value with use rather than being depleted, as the "core relationships" between trust, reciprocity and reputations for being trustworthy are positively reinforcing, leading to an upward spiral of cooperation (Ostrom 1998, 1999). In several cases, partnership capacity developed through previous management initiatives, particularly estuarine management partnerships (EMPs), had been successfully utilised. This is possibly the reason why some of those structures with two-tier management structures appeared to be successful in recruiting stakeholder participation, as the partnership capacity developed through the EMP was being built upon through the MSAC scheme preparation processes. However, unlike MSACs, EMPs do not entail any statutory obligations and it remains to be seen whether the two-tier management structures develop sufficient partnership capacity to overcome future CAPs, particularly those related to the statutory obligations for MSACs.

In one case (Cardigan Bay) a previous voluntary conservation initiative, focused on the same feature for which the MSAC was designated (bottlenose dolphin population), had developed significant partnership capacity for a part of what would later be pursued as an MSAC. However, the initial decision to shelve this initiative whilst the MSAC was being developed alienated some stakeholders and RAs and undermined the potential to develop partnership capacity. This is consistent with arguments that new management initiatives may be perceived as "competing forces" by existing forums (Steins and Edwards 1999). In another case (The Wash \& North Norfolk Coast), a previous EMP initiative had been unsuccessful in developing partnership capacity due to the lack of participation of a critical group (wildfowlers), so it was decided to develop new federated two-tier management structures for the MSAC in order to avoid this new initiative perpetuating the previous problem.

A final challenge that emerged during the case studies was the constraints on the time available to develop partnership capacity before the schemes had to be finalised, imposed by the LIFE funded $U K$ Marine SACs Project deadlines. All fifteen of the MSACs were originally consulted upon in March 1995 and the twelve LIFE MSACs were contractually required to submit final schemes by winter 2000. This provided only five years to develop the management structures and sufficient partnership capacity to support the development and subsequent implementation of the scheme. The three nonLIFE MSAC POs were also under pressure from the central NCA office to finalise their schemes, though this was not contractually binding pressure in the manner that the LIFE project deadlines were. Whilst these deadlines provided over five years for the scheme to be finalised, the 
objectives/operations advice on which the schemes are largely based was not delivered until January 1998 at the earliest and Spring 2000 at the latest. This meant that the last important stage of the scheme preparation process had to be completed in as little as 9 months. Berkes (2002) argues that building trust between actors in CPR governance may require a long time, on the order of a decade. Future work will be able to gain a longer term perspective on this critical issue.

\section{What are the likely future CAPs for the co-management of MSACs that each partnership will need to address if it is to be successful?}

The development of effective institutional arrangements for the MSACs will face many challenges over the next few years. The first is whether the MSAC management structures and processes provide for a sufficient degree of power-sharing for the state's role to shift from 'controller' to 'facilitator' (Ostrom 1990), particularly to overcome the potential mistrust by stakeholders concerning the degree to whether their participation will lead to their inclusion in decision-making processes. There is a risk that the NCAs may revert to a more controller role as their interventions shift from facilitating initial discussions and establishing the conservation objectives to the actual implementation of management programmes to ensure those objectives are actually met. As is discussed above, there is also the potential for significant legal interventions. If the NCA's Council judges risks of failure to be significant they can request certain measures be adopted, ultimately falling-back on their powers to advise the Secretary of State to utilise the statutory step-in powers to require that specific conservation measures be adopted, or the European Court of Justice may require the UK Government to step-in. Clearly, such interventions would put the NCA firmly back in a controller role, which may critically undermine the development of partnership capacity for the MSAC in question. It is argued that it is in the NCA's best interests to negotiate strategically to reflect their statutory imperatives, or occasionally even temper their facilitation role, in order to ensure that recourse to such approaches is not necessary. Whether the challenge of achieving this balance has been achieved will become clearer as MSAC schemes are presented for NCA Council approval and activities on the sites are managed over the years.

The design principles discussed above, particularly in the discussion on partnership models, arise from new institutionalism case studies that did not have externally derived statutory biodiversity conservation objectives imposed on them. The existence of such obligations means that the RAs arguably cannot leave MSAC management to self-governance by self-organised local actors. A key issue for further research will be the effects on the development of partnership capacity of the imposed management structures and asymmetrical power-sharing regimes. Steins and Edwards (1999) argue that negotiations amongst actors on CPR platforms are obstructed if strategic narratives are adopted. However, RAs arguably are bound to strategically participate in such discussions in order to ensure that their statutory obligations are fulfilled. Buck (1999) accordingly argues that the institutional imperatives of RAs should be incorporated into CPR analyses, which is consistent with the aims of this study.

A related challenge that emerged in the case studies was ensuring the development of sufficient partnership capacity amongst local stakeholders and RAs to sustain MSAC management structures and processes with a gradually decreasing level of NCA facilitation. It is unlikely that the NCAs will have the resources to employ a PO for each of the 70 MSACs in the UK that are being pursued at the time of writing, so it is important that such roles become increasingly shared amongst RAs and stakeholders. This reduces the potential for the NCA to be perceived as a controller of the MSAC but, perversely, may well increase the risks of statutory intervention should the RAs and stakeholders fail to ensure that the conservation objectives of each site are being met properly. 
The second concerns the role of contextual factors, such as those related to the externally derived statutory biodiversity conservation objectives discussed above. These external factors are likely to affect the evolution of local MSAC institutions in different ways as they inter-play with the diversity of local contextual factors which make each case essentially unique. However, many other contextual factors will also have an important influence, operating at a variety of scales, particularly given the scale and connectivity of marine ecosystems. Edwards and Steins (1999) report studies which identify up to eleven such factors which may affect the evolution of local CPR governance, and of the importance of contextual analysis being focused at different levels. Figure 4 outlines the key factors that have emerged or are likely to emerge as significant influences on the evolution of local MSAC institutions in the UK. Studies following-on from this one will pay particular attention to the influence of such factors and of the related cross-scale issues and linkages, for as Edwards and Steins (1999) argue, "context matters", though it has previously been neglected in the study of CPR regimes.

\section{[Figure 4]}

The third concerns that risk that new forms of co-management of MSACs may be undermined if the state does not recognise or fails to legitimise traditional rules of custom and practice which may have assisted the conservation of the site. For instance, voluntary rules to achieve conservation objectives may be agreed amongst stakeholders and RAs, but it is generally necessary for such rules to be legitimised by providing back-up statutory rules, to prevent local and incoming opportunists from freeriding by breaking voluntary rules in order to maximise their personal and short-term gain. Peer enforcement may be effective in many cases, but such back-up statutory rules are often essential to prevent free-riding, which also has the potential to undermine other stakeholders' willingness to cooperate, thus undermining the development of partnership capacity. As well as providing for the achievement of nature conservation objectives, such approaches also fulfil the important need for a degree of protectionism for local stakeholders (Wade 1987), albeit at the expense of the potential loss of flexibility associated with statutory controls.

This is a good example of how synergies can be created between the objectives of NCAs and the objectives of local stakeholders (Murphree 1994), in that the NCA regards local protectionism as a means of achieving nature conservation ends, whilst the stakeholders regard local protectionism as an end to be achieved through the means of nature conservation. This is particularly important given that exploitation from non-locals is widely recognised as representing one of the main threats to nature conservation, and potential alliances between RAs and local stakeholders to fend off such threats is argued to be one of the principal benefits of co-management (Borrini-Feyerabend 1999). Similarly, Rydin and Pennington (2000) recognise that there may need to be rules which prevent the participation of non-locals who have a higher potential to free-ride. It will be interesting to see whether or not such ends-means convergence through the legitimisation of local institutions emerges as a catalyst for generating partnership capacity in the MSAC case studies. It is, however, debatable whether this can overcome the basic conflict discussed above between sustainable resource exploitation and wider marine biodiversity conservation objectives at different institutional levels.

\section{Conclusions}

This paper has considered how MPA issues might be analysed by drawing on the CPR literature. It focuses in particular on issues concerning the sharing of power between stakeholders and RAs in MPA co-management regimes. It builds on the CPR literature by considering the appropriateness of "new institutionalism' approaches in contexts where there are externally derived statutory marine 
biodiversity conservation objectives. As such, it also contributes to debates concerning the comanagement of protected areas in general, particularly where such designations are subject to externally derived statutory conservation objectives, which is increasingly the case. If a balanced approach, which shares power and provides for the fulfilment of both local and statutory objectives, cannot be developed, the potential applicability of co-management approaches for nature conservation may be limited.

The preliminary findings of an ex ante study of fifteen MSAC case studies in the UK are reported, with particular reference to issues raised by the different management structures which have been adopted. The influence of CAPs which have already been raised are discussed, particularly those related to the manner in which the provision of legal advice from the NCAs was managed, how existing institutions were built upon and the constraints on the time available to develop partnership capacity. Issues for future research are highlighted, particularly those related to future CAPs posed by the attributes of the marine environment and the challenges raised by the partnership models adopted in the case studies. The latter includes the potential of different approaches for generating sufficient partnership capacity, particularly where two-tier management structures have been imposed, and whether power really is and continues to be shared on flat management structures. Other future CAPs are discussed related to the role of the state, particularly whether power can be sufficiently shared given the potential for external legal interventions, the influence of other external and local contextual factors, and the role of statutory measures to reinforce locally agreed rules in order to minimise freeriding and promote local protectionism.

As we commented at the start of this paper, it is rare to have an opportunity for the systematic study of the early stages in the design and implementation of new governance arrangements for the achievement of conservation objectives. This paper provides such a preliminary analysis of the development of partnership capacity in MSACs throughout the UK, focusing particularly on the potential of different management structures and institutions for sharing power in different contexts, with a common but critical contextual factor being the legal obligations to the EC. It will provide a basis for subsequent contextual analyses of the effectiveness of different approaches in achieving a balance to overcome the CAPs discussed above, particularly whether sufficient partnership capacity and appropriate incentive structures have been developed. It is also recognised that a critical outcome evaluation criterion will be whether the FCS of the MSACs is maintained. This is consistent with the observation reported by Conley and Moote (2003) "that whether or not a collaborative effort leads to improved environmental conditions is the ultimate measure of its success".

Berkes (2002) discusses how longer-term studies can provide for the adaptive management of local governance initiatives, "treating policies as hypotheses and management as experiments from which managers can learn". This study will form a basis for future such analyses of the development of local governance institutions for the fifteen case studies, in order to assess the relative strengths, in various contexts, of different approaches for building resilient and balanced, thereby effective, institutions for the co-management of MSACs in the UK.

\section{Acknowledgements}

We would like to thank English Nature for commissioning this research under the EC co-funded $U K$ Marine SACs Project, and Dr Darren Bhattachary and Peter Mackelworth for their help with different aspects of the project. 


\section{Notes}

1. English Nature (EN), Countryside Council for Wales (CCW), Scottish Natural Heritage (SNH) and Environment and Heritage Service, Dept of the Environment for Northern Ireland (EHS).

2. A total of eleven telephone interviews were undertaken involving nine RA representatives and two stakeholders. They were involved in the following MSACs: Plymouth Sound \& Estuaries, Thanet Coast, Strangford Lough, and Llyn Peninsular \& the Sarnau.

\section{References}

Agrawal, A. (2001) Common property institutions and sustainable governance of resources. World Development 29(10), 1649-1672

Baland, J.M. and Platteau, J. P. (1996). Halting degradation of natural resources: is there a role for rural communities? Oxford: Clarendon Press.

Berkes, F. (2002) Cross-scale institutional linkages: perspectives from the bottom up. 293-321 in E. Ostrom, T. Dietz, N. Dolšak, P.C. Stern, S. Sonich and E.U. Weber (Eds) The Drama of the Commons. Washington, DC: National Academy Press.

Borrini-Feyerabend, G. (1999) Collaborative management of protected areas. 225-234 in S. Stolton and N. Dudley (Eds) Partnerships for Protection: new strategies for planning and management for protected areas. London: Earthscan.

Buck, S.J. (1999) Multiple-use commons, collective action, and platforms for resource use negotiation. Agriculture and Human Values 16(3), 237-239.

Clifton, J. (2003) Prospects for co-management in Indonesia's marine protected areas. Marine Policy 27(5), 389-395.

Conley, A. and Moote, M.A. (2003) Evaluating collaborative natural resource management. Society and Natural Resources 16, 371-386.

Cooke, B. and Kothari, U. (2001) The case for participation as Tyranny. 1-15 in B. Cooke and U. Kothari (Eds) Participation: the new tyranny? London/New York: Zed Books.

DETR (Department of the Environment, Transport and the Regions) (1998) European Marine Sites in England and Wales: a guide to the Conservation (Natural Habitats, \&c.) Regulations 1994 and to the preparation and application of management schemes. Rotherham: DETR Publications Sale Centre.

Dietz, T., Dolšak, N., Ostrom, E. and Stern, P.C. (2002) The Drama of the Commons. 3-35 in E. Ostrom, T. Dietz, N. Dolšak, P.C. Stern, S. Sonich and E.U. Weber (Eds) The Drama of the Commons. Washington, DC: National Academy Press.

Edwards, S.D., Jones, P.J.S. and Nowell, D.E. (1997). Participation in coastal zone management initiatives: a review and analysis of examples from the UK. Ocean \& Coastal Management 36(1-3), 143-165. 
Edwards, V.M. and Steins, N.A. (1999) Special issue introduction: the importance of context in common pool resource research. Journal of Environmental Policy \& Planning 1(3), 195-204.

Geisler, C. (2002). Murphree's Law. The Common Property Resource Digest 60, 4 (http://www.indiana.edu/ iascp/E-CPR/cpr60.pdf)

Goodwin, P.P. (1998) 'Hired hands' or 'local voice': understandings and experience of local participation in conservation. Transactions of the Institute of British Geography 23(4), 481-499

Goodwin, P.P. (1999) The end of consensus? The impact of participatory initiatives on conceptions of conservation and the countryside in the United Kingdom. Environment and Planning D 17(4), 383401.

Jentoft, S. (2003) Co-management - the way forward. Fish and Fisheries Series 26, 1-16.

Jentoft, S. (2004) Institutions in fisheries: what they are, what they do, and how they change. Marine Policy 28(2), 137-149.

Jones, P.J.S. (1999) Marine nature reserves in Britain: past lessons, current status and future issues. Marine Policy 23(4-5), 375-396.

Jones, P.J.S. (2001) Marine protected area strategies: issues, divergences and the search for middle ground. Reviews in Fish Biology and Fisheries 11(3), 197-216.

Jones, P.J.S. (in press) Collective action problems posed by no-take zones. Marine Policy.

Jones, P.J.S., Burgess, J. and Bhattachary, D. (2001) An evaluation of approaches for promoting relevant authority and stakeholder participation in European marine sites in the UK. English Nature (UK Marine SACs Project). http://www.homepages.ucl.ac.uk/ ucfwpej/icem.htm\#MSAC

Kelleher, G. (1999) Guidelines for marine protected areas. Gland: IUCN.

McCay B.J. (2002) Emergence of institutions for the commons: contexts, situations and events. 361402 in E. Ostrom, T. Dietz, N. Dolšak, P.C. Stern, S. Sonich and E.U. Weber (Eds) The Drama of the Commons. Washington, DC: National Academy Press.

McCay, B.J and Jentoft, S. (1998) Market or community failure? Critical perspectives on common property research. Human Organization 57(1), 21-29.

McClanahan, T. (2004) The limits to beyond boundaries. Aquatic Conservation 14, 1-4

Murphree, M.W. (1994) The role of institutions in community-based conservation. 403-427 in D. Western, R.M. Wright and S.C. Strum (Eds) Natural Connections: perspectives in community-based conservation. Washington DC: Island Press.

Nichols, K. (1999) Coming to terms with "Integrated Coastal Management": problems of meaning and method in a new arena of resource regulation. Professional Geographer 51(3), 388-399. 
Nielsen, J.R. and Vedsmand, T. (1999) User participation and institutional change in fisheries management: a viable alternative to the failures of 'top-down' driven control? Ocean \& Coastal Management 42, 19-37.

Nielsen, J.R., Degnbol, P., Viswanathan, K.K., Ahmed, M., Hara, M. and Abdullah, N.M.R. (2004) Fisheries co-management - an institutional innovation? Lessons from South East Asia and Southern Africa. Marine Policy 28(2), 151-160.

Ostrom, E. (1990) Governing the commons: the evolution of institutions for collective action. Cambridge: Cambridge University Press.

Ostrom, E. (1998) A behavioural approach to the rational choice theory of collective action. American Political Science Review 92(1), 1-22.

Ostrom, E. (1999) Coping with tragedies of the commons. Annual Review of Political Science 2, 493535.

Pennington, M. and Rydin, Y. (2000) Researching social capital in local environmental policy contexts. Policy \& Politics 28(2), 233-49

Phillips, A. (2003) Turning ideas on their head: the new paradigm for protected areas. George Wright Forum 20(2), 8-32. www.georgewright.org/202phillips.pdf

Pinkerton, E.W. (1992). Translating legal rights into management practice: overcoming barriers to the exercise of co-management. Human Organization 51(4), 330-341.

Pomeroy, R.S., Katon, B.M. and Harkes, I. (2001) Conditions affecting the success of fisheries comanagement: lessons from Asia. Marine Policy 25(3), 197-208.

Reid, C. (2002) Nature Conservation Law. 2nd edition. Edinburgh: Green.

Rudd, M.A., Tupper, M.H., Folmer, H. and van Kooten, G.C. (2003) Policy analysis for tropical marine reserves: challenges and directions. Fish and Fisheries 4, 65-85.

Rydin, Y. and Pennington, M. (2000) Public participation and local environmental planning: the collective action problem and the potential of social capital. Local Environment 5(2), 153-169.

Selsky, J. and Creahan, S. (1996) The exploitation of common property natural resources: a social ecology perspective. Industrial \& Environmental Crisis Quarterly 9, 346-375.

Steins, N.A. and Edwards, V.M. (1999) Synthesis: platforms for collective action in multiple-use common-pool resources. Agriculture and Human Values 16(3), 309-315.

Stern, P.C., Dietz, T., Dolšak, N., Ostrom, E. and Stonich, S. (2002) Knowledge and questions after 15 years of research. 445-489 in E. Ostrom, T. Dietz, N. Dolšak, P.C. Stern, S. Sonich and E.U. Weber (Eds) The Drama of the Commons. Washington, DC: National Academy Press.

Wade, R. (1988). Village republics: economic conditions for collective action in south India. New York: Cambridge University Press. 
Walters, B.B. (2004) Local management of mangrove forests in the Philippines: successful conservation or efficient resource exploitation? Human Ecology 32(2), 177-195.

Warburton, D. A. (1998) Participation in conservation: grasping the nettle. ECOS 19(2), 2-11

Western D. and Wright R.M. (1994) The background to community-based conservation. 1-14 in D. Western, R.M. Wright and S.C. Strum (Eds) Natural Connections: perspectives in community-based conservation. Washington DC: Island Press.

Wilson D.C., Nielsen J.R. and Degnbol P., Eds (2003) The fisheries co-management experience: accomplishments, challenges, and prospects. Kluwer Fish and Fisheries Series 26. Dordrecht: Kluwer Academic Publishers.

Young, O. (2002). Institutional interplay: the environmental consequences of cross-scale interactions. 263-291 in E. Ostrom, T. Dietz, N. Dolšak, P.C. Stern, S. Sonich and E.U. Weber (Eds) The Drama of the Commons. Washington, DC: National Academy Press. 
Table 1 Attributes of the MSAC case studies

\begin{tabular}{|c|c|c|c|c|c|}
\hline & $\begin{array}{l}\text { Area } \\
\text { (ha) } \\
\text { \& type }\end{array}$ & Main economic activities & $\begin{array}{l}\text { Previous integrated } \\
\text { management } \\
\text { initiative }\end{array}$ & $\begin{array}{l}\text { No. of } \\
\text { RAs }\end{array}$ & $\begin{array}{l}\text { Approx. } \\
\text { population } \\
\text { around site }^{1}\end{array}$ \\
\hline Papa Stour $(\mathrm{SNH})$ & $\begin{array}{l}2,900 \\
\text { Island }\end{array}$ & $\begin{array}{l}\text { tourism, fishing, small-scale } \\
\text { agriculture, crafts }\end{array}$ & None & 6 & 150 \\
\hline Loch Maddy (SNH) & $\begin{array}{l}1,850 \\
\text { Bay }\end{array}$ & $\begin{array}{l}\text { mariculture, fishing, tourism, } \\
\text { small- scale agriculture, }\end{array}$ & None & 8 & 200 \\
\hline $\begin{array}{l}\text { Sound of Arisaig } \\
\text { (SNH) }\end{array}$ & $\begin{array}{l}5,300 \\
\text { Coast } \\
\end{array}$ & $\begin{array}{l}\text { tourism, mariculture, fishing, } \\
\text { small-scale agriculture }\end{array}$ & None & 7 & 1,000 \\
\hline $\begin{array}{l}\text { Solway Firth } \\
\text { (SNH/EN) }\end{array}$ & $\begin{array}{l}12,978 \\
\text { Estuary }\end{array}$ & $\begin{array}{l}\text { industry, agriculture, forestry, } \\
\text { ports, tourism, fishing, } \\
\text { recreation }\end{array}$ & $\begin{array}{l}\text { Solway Firth } \\
\text { Partnership- } \\
\text { established } 1994 \\
\end{array}$ & 16 & 100,000 \\
\hline $\begin{array}{l}\text { Berwickshire \& N. } \\
\text { Northumberland } \\
\text { Coast (SNH/EN) } \\
\end{array}$ & $\begin{array}{l}64,760 \\
\text { Coast }\end{array}$ & $\begin{array}{l}\text { fishing, agriculture, tourism, } \\
\text { recreation }\end{array}$ & None & 27 & 35,000 \\
\hline $\begin{array}{l}\text { Chesil and the Fleet } \\
(\mathrm{EN})\end{array}$ & $\begin{array}{l}694 \\
\text { Lagoon }\end{array}$ & $\begin{array}{l}\text { agriculture, commercial port at } \\
\text { its eastern end, tourism, } \\
\text { recreation }\end{array}$ & $\begin{array}{l}\text { Fleet Management } \\
\text { Group - } 1990\end{array}$ & 10 & 10,000 \\
\hline $\begin{array}{l}\text { The Wash and } \mathrm{N} \\
\text { Norfolk Coast (EN) }\end{array}$ & $\begin{array}{l}41,620 \\
\text { Estuary }\end{array}$ & $\begin{array}{l}\text { tourism, agriculture, ports } \\
\text { fishing, recreation }\end{array}$ & $\begin{array}{l}\text { Wash Estuary } \\
\text { Management } \\
\text { Group - } 1994\end{array}$ & 15 & 110,000 \\
\hline $\begin{array}{l}\text { Thanet Coast, } \\
(\mathrm{EN})^{2}\end{array}$ & $\begin{array}{l}2,269 \\
\text { Coast }\end{array}$ & $\begin{array}{l}\text { port, tourism, fishing, } \\
\text { recreation }\end{array}$ & None & 10 & 120,000 \\
\hline $\begin{array}{l}\text { Morecambe Bay } \\
(\mathrm{EN})\end{array}$ & $\begin{array}{l}17,766 \\
\text { Bay }\end{array}$ & $\begin{array}{l}\text { industry, commercial ports, } \\
\text { fishing, agriculture, tourism, } \\
\text { recreation }\end{array}$ & $\begin{array}{l}\text { Morecambe Bay } \\
\text { Partnership - } 1992\end{array}$ & 13 & 200,000 \\
\hline $\begin{array}{l}\text { Plymouth Sound and } \\
\text { Estuaries (EN) }\end{array}$ & $\begin{array}{l}3,752 \\
\text { Estuary }\end{array}$ & $\begin{array}{l}\text { commercial port, MOD, } \\
\text { fishing, recreation, tourism }\end{array}$ & $\begin{array}{l}\text { Tamar Estuaries } \\
\text { Consultative } \\
\text { Forum and Port of } \\
\text { Plymouth Liaison } \\
\text { Committee }\end{array}$ & 14 & 400,000 \\
\hline $\begin{array}{l}\text { Essex Estuaries, } \\
(\mathrm{EN})^{2}\end{array}$ & $\begin{array}{l}26,526 \\
\text { Estuaries }\end{array}$ & $\begin{array}{l}\text { agriculture, tourism, fishing, } \\
\text { recreation }\end{array}$ & $\begin{array}{l}\text { Part: Blackwater } \\
\text { Estuary } \\
\text { Management } \\
\text { Partnership - } 1992 \\
\end{array}$ & 16 & 500,000 \\
\hline $\begin{array}{l}\text { Solent/South } \\
\text { Wight Maritime } \\
(\mathrm{EN})^{2}\end{array}$ & $\begin{array}{l}22,615 \\
\text { Coast }\end{array}$ & $\begin{array}{l}\text { commercial port, industry, } \\
\text { Ministry of Defence, } \\
\text { recreation, tourism, fishing }\end{array}$ & $\begin{array}{l}\text { Solent Forum - } \\
1992\end{array}$ & 40 & $1,140,000$ \\
\hline $\begin{array}{l}\text { Cardigan Bay, } \\
(\mathrm{CCW})\end{array}$ & $\begin{array}{l}96,871 \\
\text { Coast }\end{array}$ & tourism, agriculture, fishing & $\begin{array}{l}\text { Ceredigion Marine } \\
\text { Heritage Coast - } \\
1995\end{array}$ & 9 & 10,000 \\
\hline $\begin{array}{l}\text { Llyn Peninsular \& } \\
\text { Sarnau, }(\mathrm{CCW})\end{array}$ & $\begin{array}{l}96,980 \\
\text { Coast }\end{array}$ & tourism, agriculture, fishing & None & 10 & 60,000 \\
\hline $\begin{array}{l}\text { Strangford Lough } \\
\text { (EHS) }\end{array}$ & $\begin{array}{l}15,399 \\
\text { Bay }\end{array}$ & $\begin{array}{l}\text { tourism, recreation, agriculture, } \\
\text { fishing }\end{array}$ & $\begin{array}{l}\text { Strangford Lough } \\
\text { Management } \\
\text { Committee - } 1992\end{array}$ & 4 & 60,000 \\
\hline
\end{tabular}

SNH - Scottish Natural Heritage; EN - English Nature; CCW - Countryside Council for Wales; EHS Environment and Heritage Service, Dept of the Environment for Northern Ireland (DoENI); sites bordering England/Scotland listed as EN/SNH

1 Population estimates provided by the MSAC project officers to give an indication of the number of people living around the site

2 Additional three sites which were not part of the UK Marine SACs Project 
Table 2 Management approaches and institutions adopted in the MSAC case studies

\begin{tabular}{|c|c|c|c|}
\hline & Management structure & Partnership-building approaches & Other features \\
\hline Papa Stour $(\mathrm{SNH})$ & $\begin{array}{l}\text { Flat: Advisory Panel of SHs \& } \\
\text { RAs }\end{array}$ & $\begin{array}{l}\text { Emphasis on local meetings \& } \\
\text { workshops }\end{array}$ & $\begin{array}{l}\text { LA had a key role in } \\
\text { developing the flat structure }\end{array}$ \\
\hline $\begin{array}{l}\text { Loch Maddy } \\
\text { (SNH) }\end{array}$ & Flat: MG open to SHs \& RAs & $\begin{array}{l}\text { Emphasis on local meetings \& } \\
\text { workshops; locally connected PO }\end{array}$ & $\begin{array}{l}\text { Emphasis on interpretation \& } \\
\text { awareness raising }\end{array}$ \\
\hline $\begin{array}{l}\text { Sound of Arisaig } \\
(\mathrm{SNH})\end{array}$ & $\begin{array}{l}\text { Flat: forum of RAs \& SHs with } \\
\text { tasks devolved to TGs }\end{array}$ & $\begin{array}{l}\text { Emphasis on local meetings \& } \\
\text { workshops; local PO }\end{array}$ & $\begin{array}{l}\text { LA had a key role in } \\
\text { developing the flat structure }\end{array}$ \\
\hline $\begin{array}{l}\text { Solway Firth } \\
\text { (SNH/EN) }\end{array}$ & $\begin{array}{l}\text { Two-tier: previous EMP } \\
\text { structure - RAs on MG }\end{array}$ & $\begin{array}{l}\text { SH input through previous EMP } \\
\text { initiatives }\end{array}$ & $\begin{array}{l}\text { SHs informed of MSAC } \\
\text { developments through EMP }\end{array}$ \\
\hline $\begin{array}{l}\text { Berwickshire \& } \\
\text { N. } \\
\text { Northumberland } \\
\text { Coast (SNH/EN) }\end{array}$ & $\begin{array}{l}\text { Federated two-tier: RAs on } \\
\text { MG \& SHs on three AGs, each } \\
\text { with TGs }\end{array}$ & $\begin{array}{l}\text { Regional meetings important in } \\
\text { engaging RAs in MG \& recruiting } \\
\text { SHs for AG/TGs }\end{array}$ & $\begin{array}{l}\text { AG/TG delayed due to } \mathrm{MG} \\
\text { delays, but eventually produced } \\
\text { useful issues paper }\end{array}$ \\
\hline $\begin{array}{l}\text { Chesil \& the Fleet } \\
(\mathrm{EN})\end{array}$ & $\begin{array}{l}\text { Two-tier: previous private } \\
\text { estate structure - RAs on MG; } \\
\text { SHs on AG }\end{array}$ & $\begin{array}{l}\text { Farmers not included in previous } \\
\text { AG so workshop held to involve } \\
\text { them in MSAC }\end{array}$ & $\begin{array}{l}\text { Exceptional in that most of } \\
\text { MSAC owned by private estate } \\
\text { (lagoon) }\end{array}$ \\
\hline $\begin{array}{l}\text { The Wash \& } \\
\text { North Norfolk } \\
\text { Coast (EN) }\end{array}$ & $\begin{array}{l}\text { Federated two-tier: } \text { RAs \& } \\
\text { commoners on MG, SHs on } \\
\text { AG split into three } \\
\text { geographical areas }\end{array}$ & $\begin{array}{l}\text { Former EMP structure not adopted } \\
\text { as wildfowlers did not participate in } \\
\text { this }\end{array}$ & $\begin{array}{l}\text { Local gatekeeper valuable in } \\
\text { developing participation of } \\
\text { wildfowlers }\end{array}$ \\
\hline $\begin{array}{l}\text { Thanet Coast, } \\
(\mathrm{EN})\end{array}$ & $\begin{array}{l}\text { Flat: series of SH/RA } \\
\text { participative consensus } \\
\text { building workshops but RAs } \\
\text { prepared scheme on de facto } \\
\text { MG }\end{array}$ & $\begin{array}{l}\text { Coastal action plan proposals } \\
\text { developed alongside conservation } \\
\text { proposals in order to provide a focus } \\
\text { on compatible development } \\
\text { opportunities }\end{array}$ & $\begin{array}{l}\text { EN published scheme but LA } \\
\text { has so far not published coastal } \\
\text { action plan }\end{array}$ \\
\hline $\begin{array}{l}\text { Morecambe Bay } \\
(\mathrm{EN})\end{array}$ & $\begin{array}{l}\text { Two-tier: previous EMP } \\
\text { structure - RAs on MG \& SHs } \\
\text { on AG }\end{array}$ & Former EMP structure adopted & $\begin{array}{l}\text { Emphasis on interpretation \& } \\
\text { awareness raising }\end{array}$ \\
\hline $\begin{array}{l}\text { Plymouth Sound } \\
\text { \& Estuaries (EN) }\end{array}$ & $\begin{array}{l}\text { Federated two-tier: RAs on } \\
\text { MG \& SHs on AG; one } \\
\text { separate EMP structure for } \\
\text { estuary not formerly covered }\end{array}$ & $\begin{array}{l}\text { Two former EMP structures adopted } \\
\& \text { one further EMP structure } \\
\text { developed through MSAC }\end{array}$ & $\begin{array}{l}\text { Queen's Harbour Master an } \\
\text { important champion for MSAC }\end{array}$ \\
\hline $\begin{array}{l}\text { Essex Estuaries, } \\
(\mathrm{EN})\end{array}$ & $\begin{array}{l}\text { Federated two-tier: one } \\
\text { previous EMP structure and } \\
\text { one new EMP (RAs on MG \& } \\
\text { SHs on AG), and one previous } \\
\text { Harbour Authority structure } \\
\text { (SHs/RAs on AG) }\end{array}$ & $\begin{array}{l}\text { Participative 'Future Search' } \\
\text { workshop held for one EMP }\end{array}$ & $\begin{array}{l}\text { EN PO focused on science \& } \\
\text { SH liaison; LA PO focused on } \\
\text { compatible development } \\
\text { opportunities \& strategic issues }\end{array}$ \\
\hline $\begin{array}{l}\text { Solent/South } \\
\text { Wight Maritime } \\
\text { (EN) }\end{array}$ & $\begin{array}{l}\text { Federated two-tier: RAs on } \\
\text { MSAC MG \& SHs on TGs } \\
\text { developed through EMP for } \\
\text { different issues or geographical } \\
\text { areas }\end{array}$ & $\begin{array}{l}\text { Management structure agreed by } \\
\text { RAs \& SHs through discussions } \\
\text { facilitated by EMP }\end{array}$ & $\begin{array}{l}\text { Very complex site with many } \\
\text { conflicts \& different } \\
\text { geographical areas; EMP } \\
\text { important platform for } \\
\text { discussing MSAC issues } \\
\end{array}$ \\
\hline $\begin{array}{l}\text { Cardigan Bay, } \\
(\mathrm{CCW})\end{array}$ & $\begin{array}{l}\text { Two-tier: RAs on MG \& SHs } \\
\text { on AG/TGs }\end{array}$ & $\begin{array}{l}\text { Challenges in recruiting SHs on } \\
\text { AG/TGs due to intangible role }\end{array}$ & $\begin{array}{l}\text { Former voluntary dolphin } \\
\text { conservation project subsumed } \\
\text { by MSAC: alienated some SHs }\end{array}$ \\
\hline $\begin{array}{l}\text { Llyn Peninsular \& } \\
\text { Sarnau, }(\mathrm{CCW})\end{array}$ & $\begin{array}{l}\text { Two-tier: RAs on MG \& SHs } \\
\text { on Liaison Group }\end{array}$ & $\begin{array}{l}\text { Difficult to recruit SHs on AG/TGs } \\
\text { due to intangible role so Liaison } \\
\text { Group established instead }\end{array}$ & $\begin{array}{l}\text { Geographically split nature of } \\
\text { site a hurdle to participation }\end{array}$ \\
\hline $\begin{array}{l}\text { Strangford Lough } \\
\text { (EHS) }\end{array}$ & $\begin{array}{l}\text { Two-tier: RAs on MG and SHs } \\
\text { on committee previously } \\
\text { established for MNR }\end{array}$ & $\begin{array}{l}\text { Many conflicts aired through history } \\
\text { of conservation initiatives (MNR); } \\
\text { SH committee has a major role as is } \\
\text { drafting the scheme }\end{array}$ & $\begin{array}{l}\text { Many RAs within DoENI: aids } \\
\text { RA integration; MG has main } \\
\text { decision-making powers but } \\
\text { works closely with SH } \\
\text { committee }\end{array}$ \\
\hline
\end{tabular}

AG - Advisory Group; EMP - Estuary Management Partnership; LA - Local Authority; MG - Management Group; MNR Marine Nature Reserve; PO - Project Officer; SH - Stakeholders; TG - Topic Group 
Figure 1 Nested levels of decision making interpreted for UK MSACs (after Ostrom 1990)

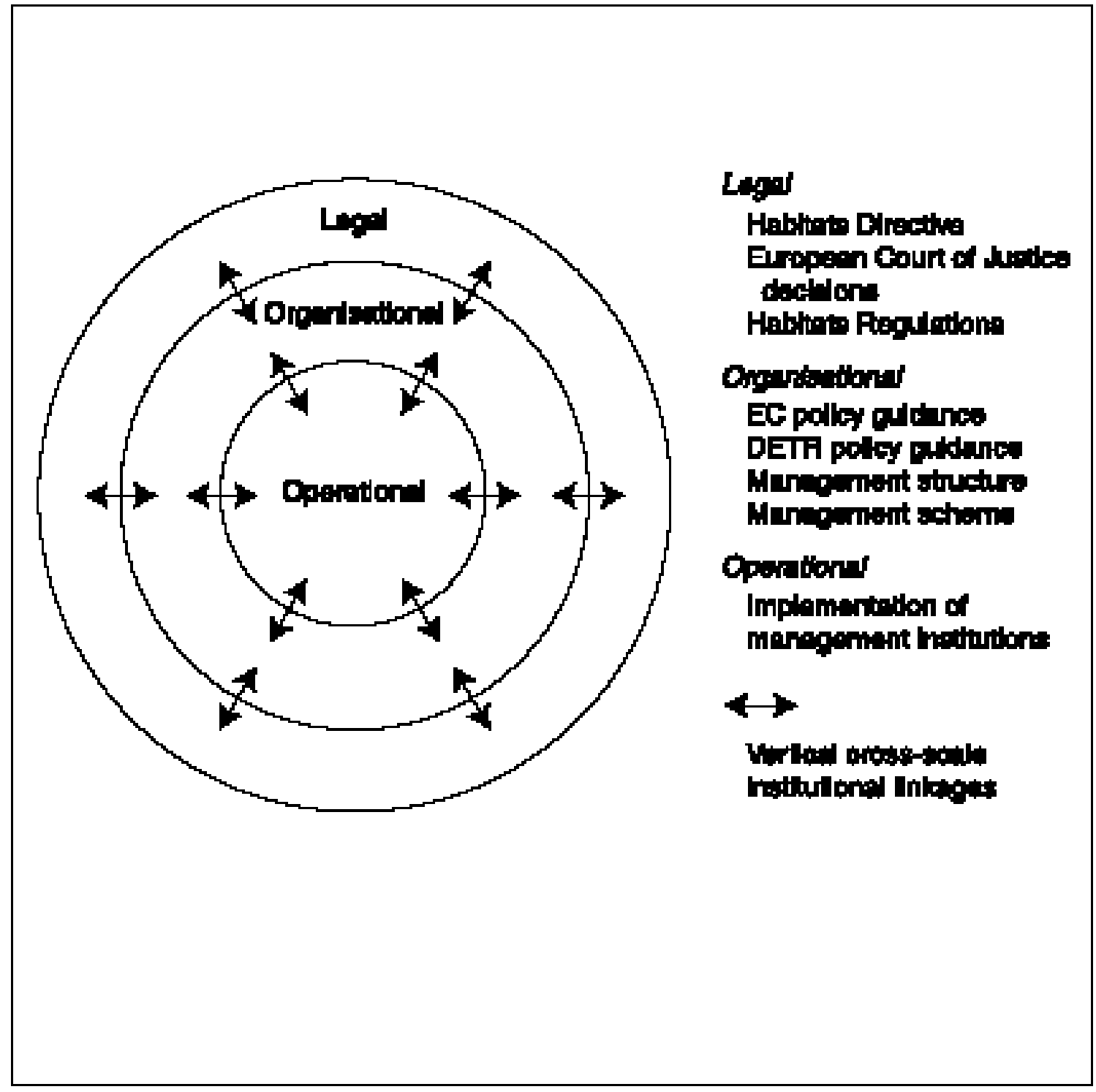


Figure 2 Case study sites and conservation features

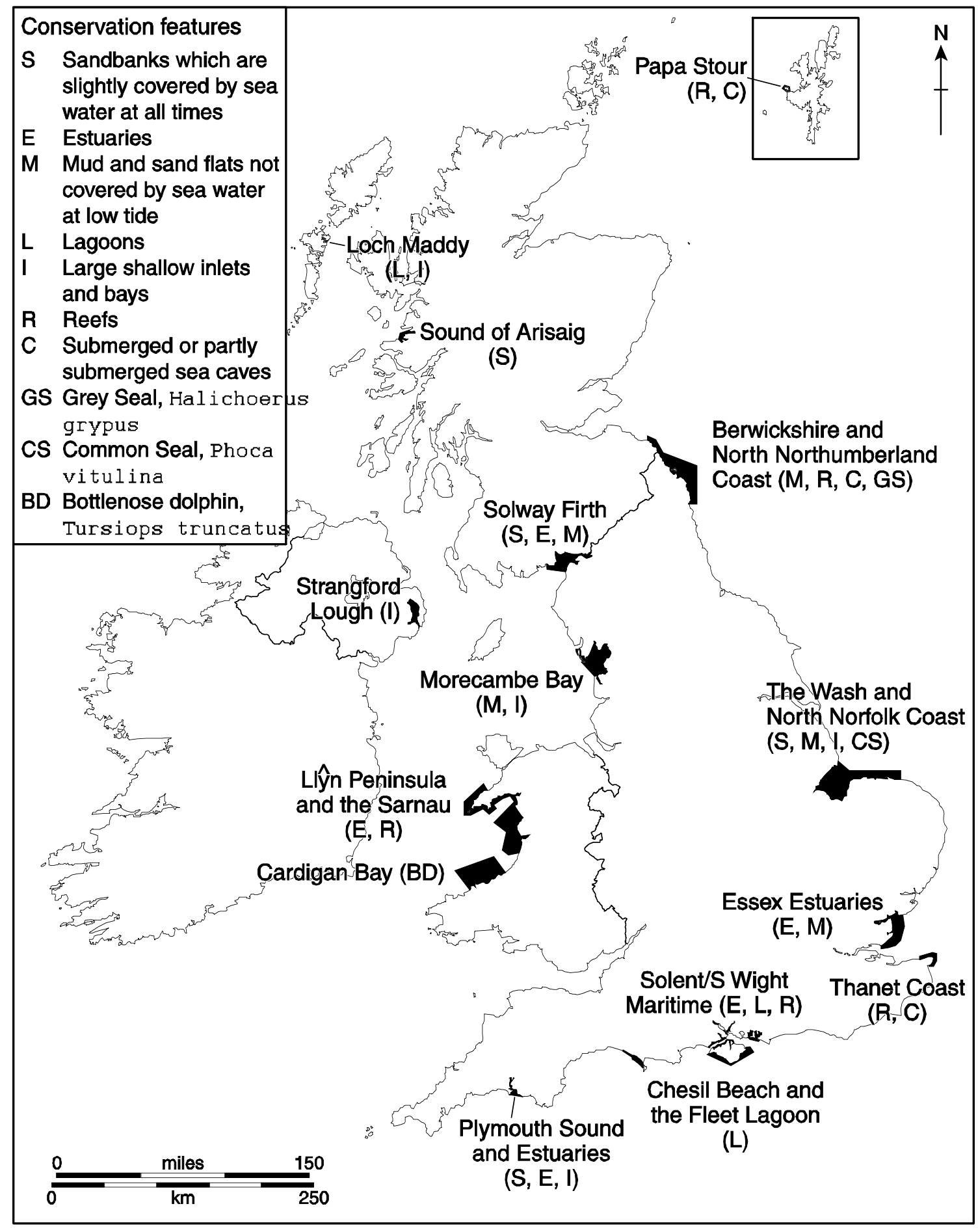


Figure 3 Main types of MSAC management structure

(A) Two-Tier; (B) Federated two-tier; (C) Flat
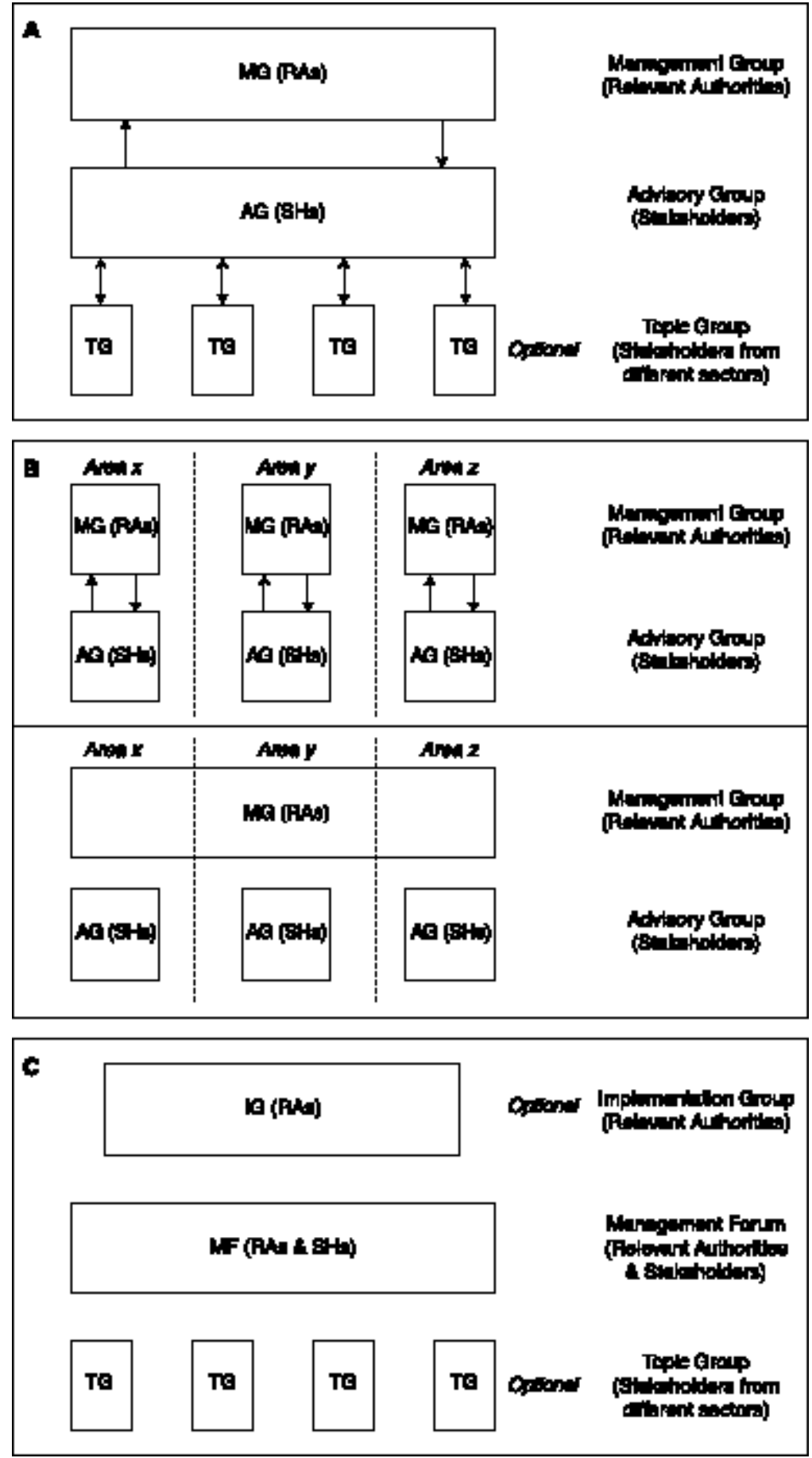
Figure 4 Contextual factors which might affect MSACs

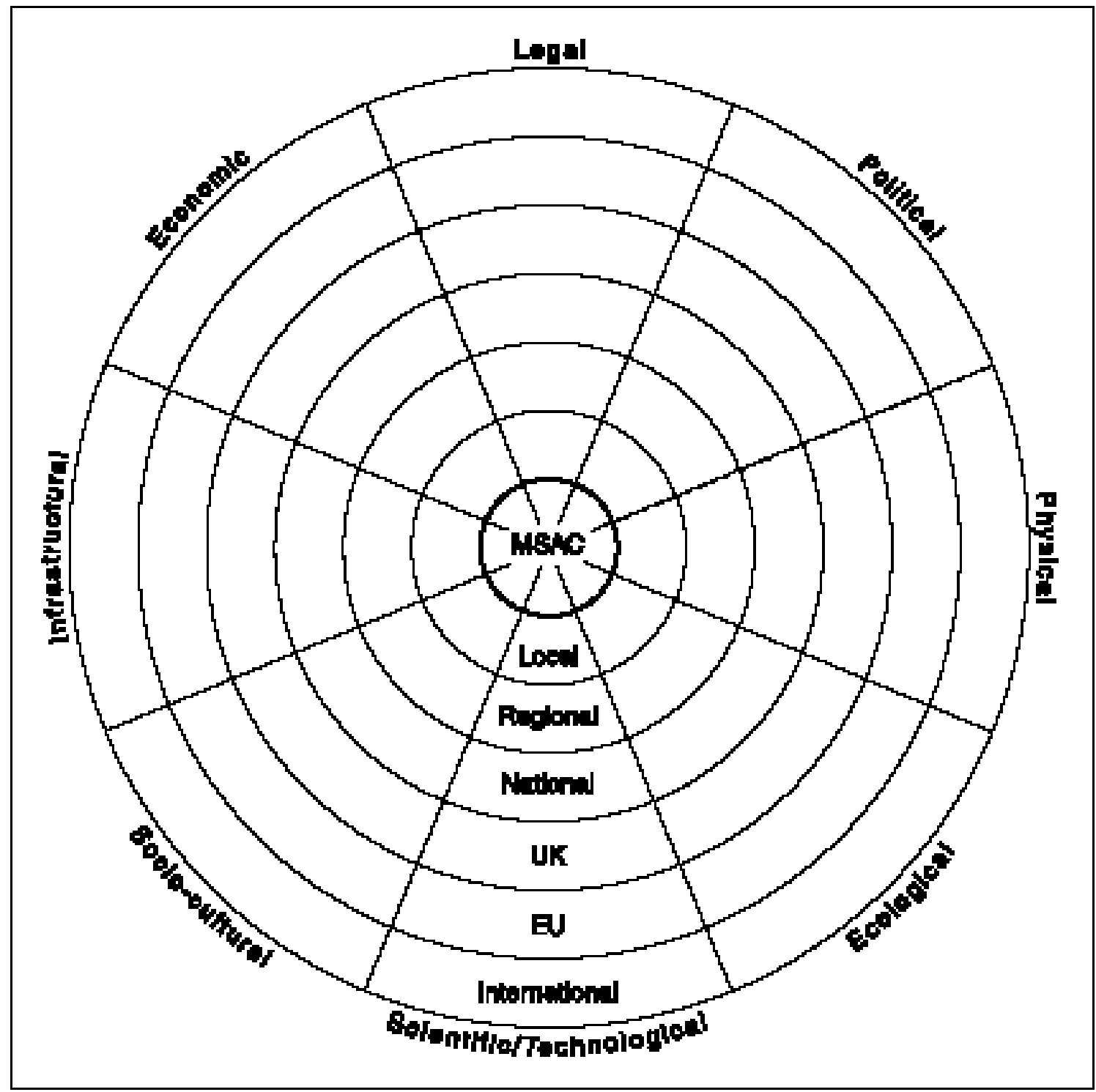

